\title{
Which Electrode Materials to Select for More Environmentally Friendly Organic Photovoltaics?
}

Espinosa Martinez, Nieves; Laurent, Alexis; Benatto, Gisele Alves dos Reis; Hösel, Markus; Krebs, Frederik C

Published in:

Advanced Engineering Materials

Link to article, DOI:

10.1002/adem.201500509

Publication date:

2016

Document Version

Peer reviewed version

Link back to DTU Orbit

Citation (APA):

Espinosa Martinez, N., Laurent, A., Benatto, G. A. D. R., Hösel, M., \& Krebs, F. C. (2016). Which Electrode Materials to Select for More Environmentally Friendly Organic Photovoltaics? Advanced Engineering Materials, 18(4), 490-495. https://doi.org/10.1002/adem.201500509

\section{General rights}

Copyright and moral rights for the publications made accessible in the public portal are retained by the authors and/or other copyright owners and it is a condition of accessing publications that users recognise and abide by the legal requirements associated with these rights.

- Users may download and print one copy of any publication from the public portal for the purpose of private study or research.

- You may not further distribute the material or use it for any profit-making activity or commercial gain

- You may freely distribute the URL identifying the publication in the public portal 


\section{Which electrode materials to select for more environmentally-}

\section{friendly organic photovoltaics?}

Nieves Espinosa, Alexis Laurent, Gisele A. dos Reis Benatto, Markus Hösel and Frederik C. Krebs*

Dr. Nieves Espinosa, Gisele A. dos Reis Benatto, Dr. Markus Hösel, Prof. Frederik C. Krebs Department of Energy Conversion and Storage, Technical University of Denmark, Frederiksborgvej 399, 4000 Roskilde, Denmark

Dr. Alexis Laurent

Division for Quantitative Sustainability Assessment, Department of Management Engineering, Technical University of Denmark, 2800 Kgs. Lyngby, Denmark

*E-mail: frkr@dtu.dk

Keywords: organic solar cells; metal electrodes; carbon; environmental impact; LCA

The transformative power of photovoltaics depends on both the cost of the system and on the cost and availability of electricity in the area of installation. For any new technology targeting large scale energy production, another challenge lies in the need for finding a solution that is as environmentally sustainable as possible, with low environmental impacts over the entire life cycle of the system, i.e. from its manufacturing through its deployment and operation up to its final disposal.

Despite having lower power conversion efficiency in its present form, the polymer solar cell technology already offers significant advantages over traditional solar cells through (i) the minimizing of material losses during the manufacturing thanks to fast and low temperature printing techniques $^{[1]}$ for the deposition of the layers, (ii) the possibility for using non-critical resources (e.g. rare earth metals), ${ }^{[2]}$ and (iii) rapid deployment of organic photovoltaics. The relatively low performance does in spite of the advantages warrant further reduction of the environmental impacts 
of the system while increasing its energy output. Through the use of life cycle assessment (LCA), which allows for quantifying environmental impacts over the entire life cycle of a technology or system, ecodesign can help move towards more environmentally-friendly organic photovoltaics. ${ }^{\text {[2] }}$

The contact electrodes in solar cells often involve the use of scarce, toxic and/or expensive materials, such as silver (for the contacts) and indium (for a transparent oxide that increases conductivity). ${ }^{[3]}$ In particular for organic photovoltaics (OPV), Indium Tin Oxide (ITO) is currently the most commonly used front electrode for OPV research at the laboratory scale. ${ }^{[4]}$ This oxide was identified in past LCA studies as a bottleneck for the technology due to its energy intensive manufacturing processes and its insufficient abundance when considering a large scale OPV deployment. Given a technology-dependent material intensity, installed PV capacity will translate directly to material requirements. ${ }^{[3][5]}$ The choice of printable materials for each layer is therefore essential to grant the low energetic, financial and environmental cost of this new technology.

There are two approaches to lessen these concerns: 1 ) to reduce the amounts of materials used and 2) to replace the critical materials. The second option with focus on replacement of those materials in use that have been demonstrated to embody environmental problems (e.g. toxicity, scarcity of the resources, large energy requirements), quickly leads to improvements in the environmental profile of the modules. However, until now, little work has been done in replacing materials used in traditional photovoltaics. In the search of replacing ITO a number of reports have been published proposing a wide range of candidates. ${ }^{[4][6]-[9]}$ However, none of these reports have assessed the environmental impacts associated with these solutions in a life cycle perspective, which thus compromises their relevance and may lead to suboptimisation since it does not address the feasibility of the solution at a real scale. One of the most promising attempts to replace ITO with a printed metal grid was the manufacturing of flexible solar modules processed by roll-to-roll (R2R) methods having silver grids as both front and back electrode ${ }^{[10][11]}$. Silver is a good candidate 
because it can be printed in a thin pattern that permits the transmission of light, only blocking a few percent of light harvesting area. The association of silver with a hole transport layer as PEDOT:PSS as a composite electrode, has been demonstrated to lead to more efficient and environmentallyfriendly devices than those using ITO. ${ }^{[12][13]}$

The bulk solar cell waste material in such a case contains elements in concentrations that are higher than the primary geological ores and from this point of view decommissioned PV technologies can be used as a secondary source. A few recent studies have started to shed light on the benefits of materials recycling and how this positively influences the environmental footprint of the PV modules. ${ }^{[2][14]}$ Silver despite having abundance similar to indium does have the advantage that it can be easily recycled from the polymer solar cell through shredding, dissolution and precipitation of AgCl. ${ }^{[14]}$ The advantage of using silver over indium meant an improvement in the energy payback time (EPBT) by a factor of four for the same performance (2\% PCE) giving an EPBT of 0.5 years. $^{[15]}$

However, silver remains a scarce metal and its large-scale use in the upscaling of the polymer solar cell technology pose a significant risk. In a recent study it was demonstrated that nearly all environmental impacts of a solar park using OPV modules with silver electrodes were dominated by the contribution from the silver electrodes. ${ }^{[2]}$ Here, we therefore explore its substitution with three other materials: carbon, copper and aluminium. The replacement of silver with carbon can bring down the energy pack back time to low levels (down to 5 months with the reported PCE values) and may imply large environmental impact savings. Aluminium and copper are both excellent conductors and present a much higher abundance than silver (or indium). Technically, all these four materials for electrodes (i.e. silver, aluminium, copper and carbon) can be roll-to-roll processed; in grid-patterns. The printing sequence and the layout of the fabricated modules can be seen in Figure 
1; see technical characteristics of the modules with different electrodes in Table 1. Detailed information is provided in Supplementary Information, Tables S-1 and S-2.

\section{FIGURE 1}

\section{TABLE 1 HERE}

Life cycle assessment, allowing for the selection of the more environmentally sustainable solution, has been applied to the four systems, covering their entire life cycles. The functional unit for comparing the four systems, i.e. the quantitative description of the main function of the systems that guarantees functionality equivalence, and thus fairness, in the comparisons, is defined as the supply of an average $1 \mathrm{kWh}$ of electricity. ITO-free modules have been tested under harsh weather conditions in Denmark and under stability protocols showing operational lifetimes over 2 years outdoors. The modules maintained the maximum power point (MPP) above T80 (the duration over which a solar cell retains above $80 \%$ of its initial MPP) over two years using a simple low-cost packaging barrier. ${ }^{[16]}$ Based on these results aluminium and copper module lifetimes are expected to have equal lifetimes. Therefore, the components of the utility, i.e. inverter, structure, cabling (the so called balance of system (BOS)) contribute equally per functional unit for all electrode options and can therefore be disregarded. The considered system boundaries are outlined in Figure 2. The life cycle stages include (i) the raw materials extraction to produce the different components of the OPV modules, (ii) the manufacturing of OPV modules as currently taking place in Denmark, (iii) the operational phase, where maintenance is neglected, and (iv) the disposal of the modules, which are modelled as either being recycled or incinerated (with energy recovery). Crediting of the thusrecovered materials and energy, which substitute the production of virgin materials or the 
generation of energy by conventional means, was performed using system expansion in the modelling.

\section{FIGURE 2 HERE}

For the production stage (since OPV modules are fabricated on a pilot-scale at the Technical University of Denmark that leads to highly representative data) background life cycle inventories from the ecoinvent database ${ }^{[17]}$ were combined with the known materials and energy requirements for the manufacture of the OPV modules. Aggregated life cycle inventories of the materials extraction, the production and the disposal of the four electrodes were built based on the requirements. The electrode ink composition and the rest of the components are available in Table S-1 and S-3, in the Supplementary Information. The complete model of solar cells based on silver electrodes, has been detailed in the literature ${ }^{[2]}$ and the same model is used here with the adaptation of electrode materials and associated processes. The carbon-based metal-free version is based on the principle structure presented earlier. ${ }^{[18]}$ Three scenarios for the disposal of the OPV modules were considered following the model established already. ${ }^{[2]}$ These include a recycling route (DK-1), where the modules are recycled to recover the electrode materials and some of the plastic insulator prior to being sent to incineration (with energy recovery); an incineration route (DK-2), where the modules are directly sent to incineration with energy recovery; and an average route (DK-3), which present the municipal solid waste management landscape for Denmark, i.e. 29 \% recycling, 69\% incineration and 2\% landfill. Further details about the modelled scenarios can be found in the literature ${ }^{[2]}$ and in the Supplementary Information.

Total pollutant emissions and resource consumptions derived from the production, installation and decommission of the solar cells, are translated into potential impact indicator scores by use of life cycle impact assessment (LCIA) methods. The International Reference Life Cycle Data System (ILCD) methodology (ILCD 2011 v1.04, in SimaPro 8.0.4.26 software ${ }^{[19]}$ ) was used as it is 
recommended best practice in LCIA. ${ }^{[20]}$ The LCA community agrees that the key areas of protection are human health, natural resources, the natural environment, and the "manmade" environment. The assessed impact categories therefore include climate change, toxicity of chemicals to human health (termed 'human toxicity'), differentiated between carcinogenic effects and non-carcinogenic effects, toxicity of chemicals impacting freshwater ecosystems (termed 'freshwater ecotoxicity'), eutrophication in freshwater and marine environments, respiratory impacts caused by inorganics via formation of particulate matters (termed 'respiratory inorganics'), ionising radiation impacting human health, land use, and non-renewable resource depletion. Detailed descriptions and sources of the different LCIA methods for each of these impact categories have been published elsewhere. ${ }^{[21][22]}$ Figure 3 illustrates the impact scores of the four systems with differentiation between the three considered disposal scenarios.

\section{FIGURE 3 HERE}

The obtained results can be distinguished between the metal-based modules and the carbon-based modules. The metal-based electrode modules are those presenting the largest environmental impacts. With the exception of climate change, stratospheric ozone depletion and water resource depletion, which are a factor of ca. 2-5 higher, all impact indicator scores for metal-based OPV modules generally are one order of magnitude higher than the carbon-based modules (see Tables S-7-S-10). For impacts such as non-renewables resource depletion (metals, fossils) and chemical pollution impacting human health (termed human toxicity), the differences reach up to two orders of magnitude . Among the metal-based alternatives, silver use leads to the largest impacts because of its high toxicity when emitted to the environment, its relatively high scarcity and its important energy requirements for mining and production processes. 
The manufacturing of metal-based modules has considerably higher impact scores than the carbon. The highest contribution for the emissions in the production of the metal-based electrode modules is the back electrode which consists of silver in all of them. As reflected by the carbon-based system, the substitution of the back metal electrode with lower-impact materials (still meeting technical specifications of low sheet resistivity, roll-to-roll printing compatibility) can bring significant environmental benefits to the systems. The material substitution for that electrode should thus be prioritised by OPV designers.

The largest impacts in the manufacturing are offset by the benefits in the disposal for all systems because of recovered materials and energy. Recycling of modules represents the most beneficial option for metal-based modules because the relatively efficient recovery of metals, i.e. ca. $72 \%$, ${ }^{[2]}$ saves impacts associated with the production of virgin metals.

In contrast, the type of waste management for the carbon-based modules lead to more nuanced results. Solar cells are made of $80-90 \%$ by weight of PET. When the production of virgin polymers is avoided because of recycled polymers at rates close to $100 \%$, the recycling scenario is more advantageous than that of incineration with energy recovery. ${ }^{[23]}$ However, for some impact categories, such as freshwater ecotoxicity or human toxicity, the energy required for the recycling of carbon electrodes contributes to give the recycling scenario a higher impact score than if they are incinerated with energy recovery. The large efficiencies of the Danish incinerators also contribute to such results. ${ }^{[24]}$ For the average scenario, where $69 \%$ of components are incinerated, $29 \%$ is recycled and $2 \%$ is landfilled, the impact scores for the four systems across impact categories logically lies in between the scores for recycling and the scores for incineration. These findings therefore suggest that in the presence of high value materials such as metals in OPV modules, recycling should be prioritised by stakeholders because it not only saves the extraction of scarce resources but also leads to overall decrease of the environmental burden. For such purposes, take- 
back systems, as generally advocated, ${ }^{[2]}$ could be implemented to put responsibility on the manufacturer or operator of the solar park. From this explorative study, metal-electrode-based OPV seem to perform significantly poorer than carbon-based-electrode OPV modules with respect to all analysed environmental indicators. Metal-electrodes, such as silver, have been demonstrated to be large contributors to the environmental impacts of the OPV modules, and their substitution by other types of materials, such as carbon, should therefore be further investigated by system designers and researchers in the PV field. Figure 4 provides an overview of "pros and cons" in the use of silver and carbon in OPV modules. From the results above, carbon modules are good candidates to be incinerated and energy can be recovered. In comparison with the metal electrode based modules, the harm is lower as well in the case they end up their lives disposed in landfills or in an uncontrolled environment. However, carbon-based module architecture is derived from the low conductivity of carbon. As it has been described by dos Reis Benatto et al., ${ }^{[18]}$ this fact imposes that the modules have to be smaller. The edges require extra sealing. The area usage is not optimal, which makes that despite the efficiency per active area is equal to those modules metal based electrodes (the cell efficiency), when the total area is computed the power conversion efficiency becomes smaller. Carbon based OPV produced at the pilot-scale, with 1\% efficiency has been compared to traditional inorganic modules (i.e. silicon solar cells), manufactured in large production volumes. The comparison of the production of $1 \mathrm{kWh}$ reveals that despite carbon modules have lower efficiency nearly all impact categories are lower than those for Si panels. There is only one impact category, the climate change impact that is $30 \%$ higher; for the rest of categories silicon PV panels largely exceed the organic modules scores - ranging from 1.6 to 8.5 times higher. Significantly high is the impact for resource depletion stemming from the fact that Si panels rely on several metals for their production (Table S-11 in Supplementary Information shows all the scores). The recommended research effort of moving to metal free-electrodes should be conducted hand-in-hand with 
improving the coverage of the modules when printing, in order to enhance their efficiencies which consequently decreases the environmental footprint of the OPV technology per unit of energy output.

\section{FIGURE 4 HERE}

\section{Experimental section}

Materials: The electrode materials employed in this study are a silver nanoparticle ink (Novacentrix PChem PFI-722) for the front electrode and silver flake paste (Dupont 5025) for the back electrode. Aluminium ink followed an in house recipe. For the manufacturing, a ball mill is used to convert the aluminium into the precise flakes that are required for the ink to be usable. Copper oxide based ink has been purchased from Novacentrix (ICI-021). Carbon ink was purchased from Acheson (Electrodag PF-407), that contains graphite and carbon black. For the rest of the materials employed in the solar stack, data can be found elsewhere. ${ }^{[18][25]}$

Device preparation: The solar cells were produced entirely using roll-to-roll equipment entirely under ambient conditions. The manufacturing was carried out using flexographic printing, slot-die coating, and rotary screen printing at speeds up to $20 \mathrm{~m} \mathrm{~min}^{-1}$. The details are described

elsewhere $^{[15][18][25]}$. The necessary photonic sintering process to reduce $\mathrm{CuO}$ to a conductive $\mathrm{Cu}$ layer could not be carried out satisfactorily. Two different commercial flash systems (Novacentrix and Xenon Sinteron) have been carefully tested but the flexo printed $\mathrm{CuO}$ layer was to thin and porous in the microscopic range. Compact, but too thick, screen printed layers could be easily flashed to achieve conductivity. Insufficient post-treatment of $\mathrm{CuO}$ ink and the challenging processing of $\mathrm{Al}$ ink under inert atmosphere resulted in a pure theoretical evaluation of these two 
metal grids. Furthermore, $\mathrm{CuO}$ ink cannot be used as back electrode, since photonic sintering destroy the preprinted layers due to their high absorbance of light.

\section{Supporting Information}

See below.

\section{Acknowledgements}

N.E., G.D.B. and F.C.K acknowledge funding from a Sapere Aude Top Scientist grant (no. DFF 1335-00037A).

\section{References}

[1] F.C. Krebs, Org. Electron. 2009, 10, 761.

[2] N. Espinosa, A. Laurent, F.C. Krebs, Energy Environ. Sci. 2015. DOI: 10.1039/c5ee01763g

[3] J. Jean, P.R. Brown, R.L. Jaffe, T. Buonassisi, V. Bulović, Energy Environ. Sci. 2015, 8, 1200.

[4] D. Angmo, N. Espinosa, F. Krebs, in Low-Cost Nanomater. (Eds: Z. Lin, J. Wang), Springer London, London 2014, 189.

[5] R.L. Moss, E. Tzimas, H. Kara, P. Willis, J. Kooroshy, Critical Metals in Strategic Energy Technologies - SETIS, European Commission, Joint Research Centre, Luxembourg 2011.

[6] M.W. Rowell, M.A. Topinka, M.D. McGehee, H.-J. Prall, G. Dennler, N.S. Sariciftci, L. Hu, G. Gruner, Appl. Phys. Lett. 2006, 88, 233506.

[7] Y.H. Kim, C. Sachse, M.L. Machala, C. May, L. Müller-Meskamp, K. Leo, Adv. Funct. Mater. 2011, 21, 1076.

[8] D. Angmo, F.C. Krebs, J. Appl. Polym. Sci. 2013, 129, 1.

[9] Y. Galagan, B. Zimmermann, E.W.C. Coenen, M. Jørgensen, D.M. Tanenbaum, F.C. Krebs, H. Gorter, S. Sabik, L.H. Slooff, S.C. Veenstra, J.M. Kroon, R. Andriessen, Adv. Energy Mater. 2012, 2, 103.

[10] M. Hösel, R.R. Søndergaard, M. Jørgensen, F.C. Krebs, Energy Technol. 2013, 1, 102.

[11] P. Sommer-Larsen, M. Jørgensen, R.R. Søndergaard, M. Hösel, F.C. Krebs, Energy Technol. 2013, 1, 15.

[12] N. Espinosa, R. García-Valverde, A. Urbina, F. Lenzmann, M. Manceau, D. Angmo, F.C. Krebs, Sol. Energy Mater. Sol. Cells 2012, 97, 3.

[13] C.J.M. Emmott, A. Urbina, J. Nelson, Sol. Energy Mater. Sol. Cells 2012, 97, 14. 
[14] R.R. Søndergaard, N. Espinosa, M. Jørgensen, F.C. Krebs, Energy Environ. Sci. 2014, 7, 1006.

[15] F.C. Krebs, N. Espinosa, M. Hösel, R.R. Søndergaard, M. Jørgensen, Adv. Mater. 2014, $26,29$.

[16] D. Angmo, F.C. Krebs, Energy Technol. 2015, 3, 774.

[17] The Ecoinvent Database v3.1. Swiss Centre for Life Cycle Inventories, Ecoinvent Centre2014.

[18] G.A. dos Reis Benatto, B. Roth, M.V. Madsen, M. Hösel, R.R. Søndergaard, M. Jørgensen, F.C. Krebs, Adv. Energy Mater. 2014, 4, 1614.

[19] SimaPro 8.0.4.26, PRé Consultants, Amersfoort, NL 2015.

[20] M.Z. Hauschild, M. Goedkoop, J. Guinée, R. Heijungs, M. Huijbregts, O. Jolliet, M. Margni, A. De Schryver, S. Humbert, A. Laurent, S. Sala, R. Pant, Int. J. Life Cycle Assess. 2013, 18, 683.

[21] A. Laurent, S.I. Olsen, M.Z. Hauschild, Environ. Sci. Technol. 2012, 46, 4100.

[22] A. Laurent, N. Espinosa, Energy Environ. Sci. 2015, 8, 689.

[23] J.C. Michaud, L. Farrant, O. Jan, B. Kjaer, I. Bakas, Waste Resour. Action Programme Banbury 2010.

[24] Energinet (2015) Personal Communication (February 2015)

[25] F.C. Krebs, M. Hösel, M. Corazza, B. Roth, M.V. Madsen, S.A. Gevorgyan, R.R. Søndergaard, D. Karg, M. Jørgensen, Energy Technol. 2013, 1, 378.

[26] J.H. Schmidt, Plastberegner.dk - LCA Tool for Plastics Converters in Denmark Documentation of the Tool and Database, 2012. 
Table 1. Characteristics of the four electrodes analysed. More details in Tables S1 and S2 in Supplementary Information.

\begin{tabular}{|c|c|c|c|c|}
\hline & Silver & Aluminium & Copper & Carbon \\
\hline Cell Efficiency & $2 \%$ & $2 \%$ & $2 \%$ & $2 \%$ \\
\hline Geometric fill factor $^{a}$ & $50 \%$ & $50 \%$ & $50 \%$ & $36.80 \%$ \\
\hline Module efficiency & $1 \%$ & $1 \%$ & $1 \%$ & $0.7 \%$ \\
\hline Electrode & Front/Back & Front & Front & Back \\
\hline Solid content in ink & $60 \% \mathrm{Ag}$ & $40 \% \mathrm{Al}$ & $50 \% \mathrm{Cu}$ & $29 \% \mathrm{C}$ \\
\hline
\end{tabular}

${ }^{a}$ Based on the current design of fabricated modules at DTU. Not yet fully optimized 

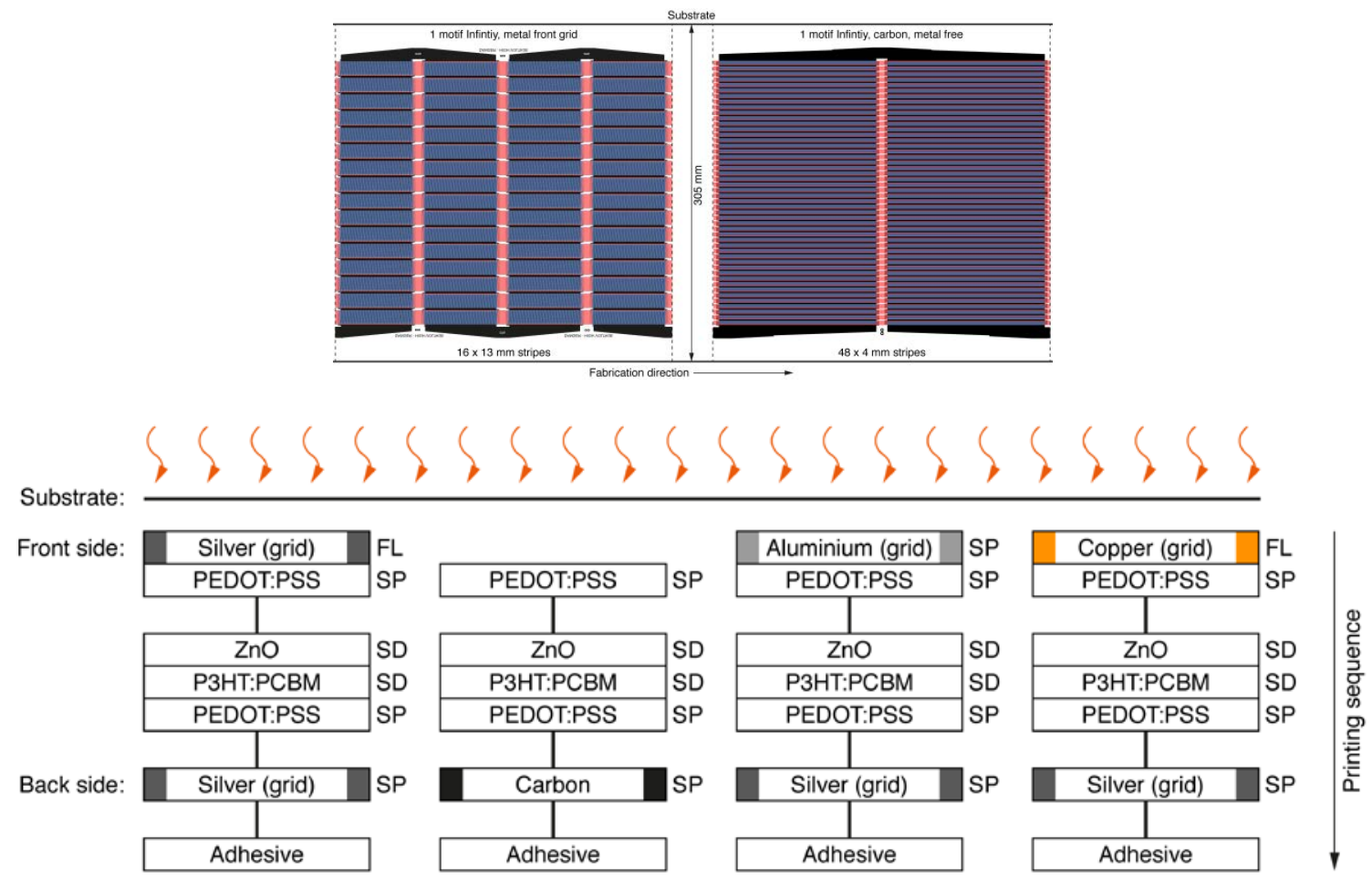

(a)

(b)

(c)

(d)

Figure 1. Top. Layout of the fabricated modules used for the calculations in this study, on the left the pattern for the metal grids ( $\mathrm{Ag}, \mathrm{Al}, \mathrm{Cu}$ ) and on the right the pattern for carbon based solar cells. The carbon based design was evaluated based on the previously manufactured freeOPV solar cells. The exploitation of the different layers that form them is shown below. 
Espinosa N., Laurent A., dos Reis Benatto G.A., Hösel M., Krebs F.C. 2016. Which electrode materials to select for more environmentally-friendly organic photovoltaics? Advanced Engineering Materials 18, 490-495. DOI: 10.1002/adem.201500509.

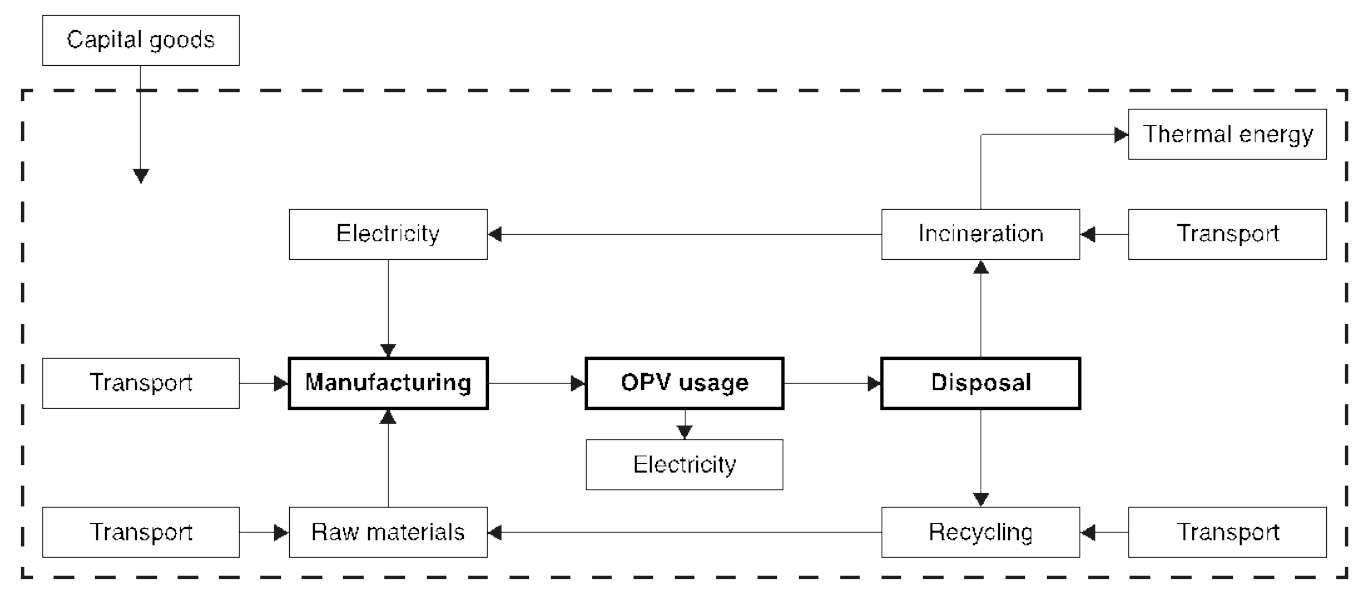

Figure 2. Life-cycle stages of the OPV modules. From left to right the main processes are the manufacturing, involving the use of raw materials, energy and transport, followed by the usage and the disposal stage, where the two alternatives explored have been shown; recycling and incineration. 

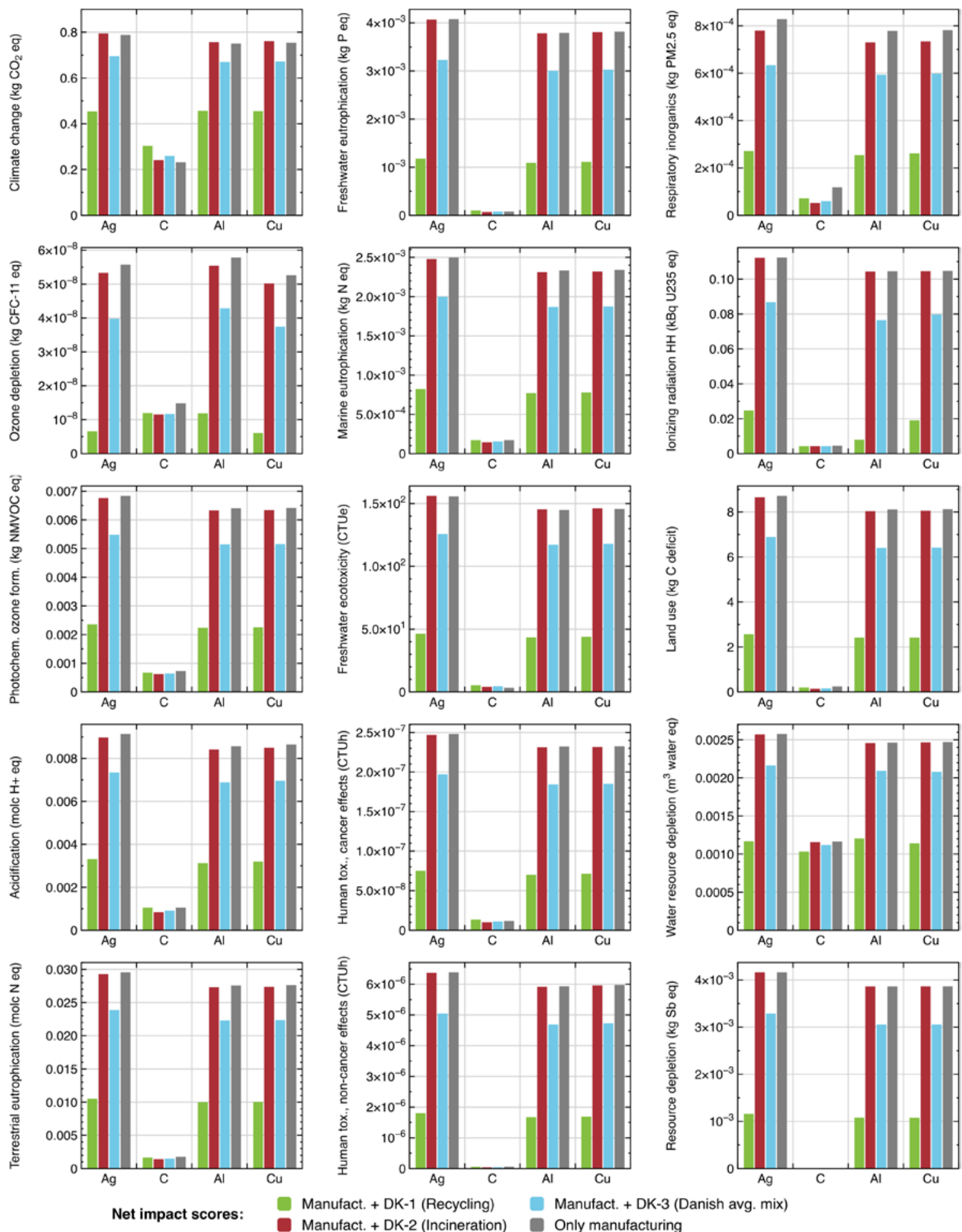

Figure 3. Net ILCD 2011 v1.04 impact scores for 1kWh OPV modules with the different electrodes.

The considered disposal under the three scenarios for waste management is shown versus the manufacturing to compare. Normalized impact scores are given in Tables S-7 to S-10 and shown in Figure S-1, in Supplementary Information. 
Espinosa N., Laurent A., dos Reis Benatto G.A., Hösel M., Krebs F.C. 2016. Which electrode materials to select for more environmentally-friendly organic photovoltaics? Advanced Engineering Materials 18, 490-495. DOI: 10.1002/adem.201500509.

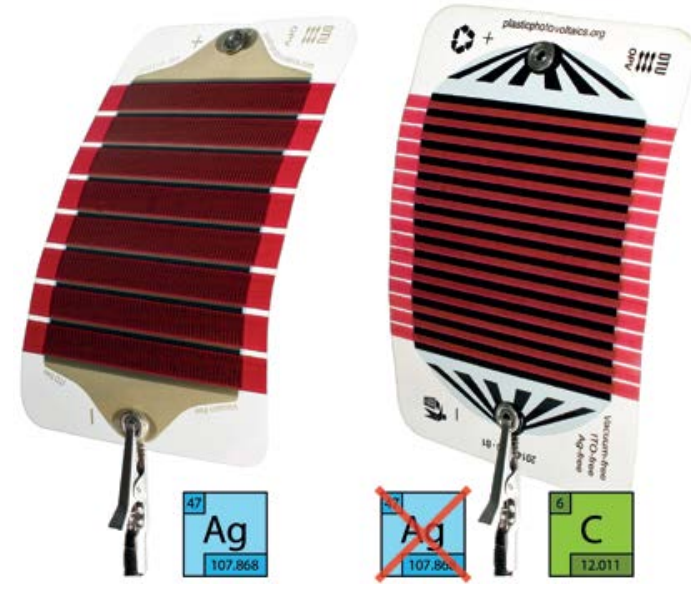

\begin{tabular}{ll}
\hline Silver & Carbon \\
\hline Low usage & Moderate usage \\
High conductivity & Low conductivity \\
Higher performance & Low performance \\
High active area cells & Low active area ${ }^{\mathrm{a}}$
\end{tabular}

Toxicity problems $\quad$ Non toxic

Scarce Abundant

High cost Low cost

High recyclability ${ }^{\mathrm{b}} \quad$ Highly recyclable

${ }^{a}$ Narrower stripes are required consequently

${ }^{\mathrm{b}}$ limited to a high degree of collection

Figure 4. Comparison of Silver and Carbon. Image of organic solar cells printed in freeOPV pattern ${ }^{[18]}$, either with silver or carbon, where are shown the requirements of edge sealing, bus-bars and connectors. Balance or list with the advantages, disadvantages and the precautions of using one or another. 


\section{Highlight}

The effect of substituting the metal electrode materials in organic solar cells has been demonstrated to reduce significantly the environmental impacts of this technology. Four alternatives have been assessed and the conclusion is that other types of materials, such as carbon, should be further investigated by system designers and researchers in the PV field.

\section{Keywords}

Organic solar cells; metal electrodes; carbon; environmental impact; LCA

\section{TOC}

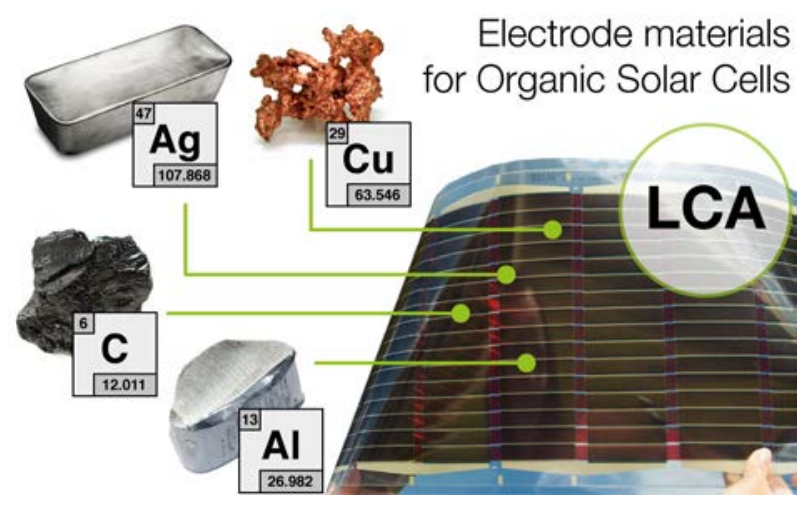




\section{Supporting Information}

\section{Which electrode materials to select for more environmentally-}

\section{friendly organic photovoltaics?}

Nieves Espinosa, Alexis Laurent, Gisele A. dos Reis Benatto, Markus Hösel and Frederik C. Krebs*

\section{The choices of metal electrodes for OPV}

Silver, carbon, copper and aluminium all have excellent properties that make them ideal to be part of organic solar cells, but also drawbacks. Silver unique properties of ductility, reflectivity and being the most conductive of all metals, make it interesting for its use as electrode. The relatively high cost, and scarcity (the world demand for silver is $25 \%$ higher than the current production) already impose a high recycling rate. Carbon based solar cells have been proved as being the "ultimate electrode" due to its superiority with regard to material availability, cost and easy deposition. Carbon electrodes for electronics usually are in the form of an ink containing graphite and carbon black and abundant graphite that can be processed by roll to roll. The suitability of Aluminium as an electrode material has also been evaluated due to its potential: it is the most abundant metal in earth crust; it is light, cheap and has good mechanical properties for flexible devices such as organic solar cells. The mining of aluminium and extraction from bauxite demands a high energy input, which imposes (as in the case of silver) recycling practices. Copper is a widely used metal due its good conductivity, corrosion resistance and relatively low cost. It is therefore also a suitable candidate for electrodes in OPV modules. Like aluminium, to form a thin conductive 
layer copper needs to be cured, which can limit the use of flexible substrates like PET. Except for carbon solar cells, the environmental impact in uncontrolled disposal can be a threat to the environment and humans; especially copper and silver are toxic to all living cells. All the properties and features of the four materials are shown below in Table S-1.

Table S-1. Reserves, prices and recyclability of silver, aluminium, copper and graphite

\begin{tabular}{|c|c|c|c|c|}
\hline & Silver $^{a}$ & Carbon ${ }^{b}$ & Aluminium $^{c}$ & Copper $^{d}$ \\
\hline $\begin{array}{l}\text { Reserves } \\
\text { (million tons) }\end{array}$ & 0.54 & $130-800$ & 28000 & 690 \\
\hline $\begin{array}{l}\text { Price } \\
\text { (US\$/Kg) }\end{array}$ & 672.69 & 1.3 & 1.95 & 7.11 \\
\hline Recyclability & High & $\begin{array}{l}\text { Low. Usually } \\
\text { recycled with other } \\
\text { similar PET based } \\
\text { products or safely } \\
\text { disposed in normal }\end{array}$ & $\begin{array}{l}\text { High. Around } 18 \\
\text { million tones/yr. } \\
\text { Ca. } 75 \% \text { of the } \\
\text { aluminium ever } \\
\text { mined is still in use }\end{array}$ & $\begin{array}{l}\text { Very high }(1 / 3) \\
\text { remelted and used } \\
\text { directly without } \\
\text { losing any property }\end{array}$ \\
\hline $\begin{array}{l}\text { Deposition/ } \\
\text { Printability }\end{array}$ & $\begin{array}{l}\text { - Vacuum-free } \\
\text { processing } \\
\text { - Screen, flexo } \\
\text { printing and } \\
\text { several other } \\
\text { printing } \\
\text { techniques. } \\
\text { - No need for } \\
\text { curing process. }\end{array}$ & $\begin{array}{l}\text { - Screen-printing in } \\
\text { air } \\
\text { - None especial } \\
\text { after treatments }\end{array}$ & $\begin{array}{l}\text { Evaporated/Printed } \\
\text { in vacuum chambers } \\
\text {-to prevent the } \\
\text { oxidation. }\end{array}$ & $\begin{array}{l}\text { - deposited in } \\
\text { controlled } \\
\text { atmosphere } \\
\text { - cured under very } \\
\text { high energy light } \\
\text { or temperature. }\end{array}$ \\
\hline $\begin{array}{l}\text { Conductivity } \\
\text { (S/m) }\end{array}$ & $6.30 \times 10^{7}$ & $\begin{array}{ll}2.00 \times 10^{5} & \text { to } \\
3.00 \times 10^{5} & \end{array}$ & $3.50 \times 10^{7}$ & $5.96 \times 10^{7}$ \\
\hline
\end{tabular}

${ }^{a}$ For silver: L. Grandell and A. Thorenz, "Silver supply risk analysis for the solar sector,” Renew. Energy, vol. 69, pp. 157-165, Sep. 2014.

R. Søndergaard, M. Helgesen, M. Jørgensen, and F. C. Krebs, Adv. Energy Mater., vol. 1, no. 1, pp. 68-71, 2011.

J.-S. Yu, I. Kim, J.-S. Kim, J. Jo, T. T. Larsen-Olsen, R. R. Søndergaard, M. Hösel, D. Angmo, M. Jørgensen, and F. C. Krebs, Nanoscale, vol. 4, no. 19, pp. 6032-40, Sep. 2012.

F. C. Krebs, Sol. Energy Mater. Sol. Cells, vol. 93, no. 4, pp. 394-412, Apr. 2009.

http://www.indexmundi.com/commodities/?commodity=silver

${ }^{\mathrm{b}}$ Carbon: 2012 Minerals Yearbook, Donald W. Olson, 2012 USGS.

http://minerals.usgs.gov/minerals/pubs/commodity/graphite/myb1-2012-graph.pdf

http://northerngraphite.com/graphite-labs/graphite-price/

${ }^{\text {c }}$ For aluminium: T. E. Norgate, S. Jahanshahi, and W. J. Rankin, J. Clean. Prod., vol. 15, no. 8-9, pp. 838-848, Jan. 2007.

http://www.indexmundi.com/commodities/?commodity=aluminum

Y. Zhou, C. Fuentes-Hernandez, T. M. Khan, J.-C. Liu, J. Hsu, J. W. Shim, A. Dindar, J. P. Youngblood, R. J. Moon, and B. Kippelen, Sci. Rep., vol. 3, p. 1536, Jan. 2013.

${ }^{\mathrm{d}}$ Copper: Commodity Statistics and Information. Minerals Information, USGS.

http://minerals.usgs.gov/minerals/pubs/commodity/copper/mcs-2014-coppe.pdf

http://www.indexmundi.com/commodities/?commodity=copper

P. Plunkert, "Bauxite and alumina,” US Geol. Surv. Miner. Yearb. ..., vol. 1, no. December 2012, pp. 26-27, 2007.

\section{Material preparation}


In Table S-2 the components for each ink used as electrode are shown. Silver, Copper and Carbon are commercial inks, while aluminium ink is an in house recipe. For its manufacturing, a ball mill is used to convert the aluminium into the precise flakes that are required for the ink to be usable. Intuitively, the energy consumed for this process can be largely different depending on the scale at which the process is done. We have supposed here a large mill that can process.

Table S-2. Materials required of each ink for electrodes used in the electrodes.

\begin{tabular}{|c|c|c|}
\hline INK COMPONENTS & Amount & Unit \\
\hline Front Ag-ink & 1 & $\mathrm{~kg}$ \\
\hline Silver & 0,6 & $\mathrm{~kg}$ \\
\hline Water, deionised, from tap water & 0,4 & $\mathrm{~kg}$ \\
\hline Front Al-ink & 1 & $\mathrm{~kg}$ \\
\hline Aluminium, primary, liquid & 0,4 & $\mathrm{~kg}$ \\
\hline Solvent, organic & 0,6 & $\mathrm{~kg}$ \\
\hline Front Cu-ink & 1 & $\mathrm{~kg}$ \\
\hline Copper oxide & 0,5 & $\mathrm{~kg}$ \\
\hline Water, deionised, from tap water & 0,5 & $\mathrm{~kg}$ \\
\hline Back C ink & 1 & $\mathrm{~kg}$ \\
\hline Graphite & 0,21 & $\mathrm{~kg}$ \\
\hline Carbon black & 0,08 & $\mathrm{~kg}$ \\
\hline Dipropylene glycol monomethyl ether & 0,71 & $\mathrm{~kg}$ \\
\hline
\end{tabular}


Espinosa N., Laurent A., dos Reis Benatto G.A., Hösel M., Krebs F.C. 2016. Which electrode materials to select for more environmentally-friendly organic photovoltaics? Advanced Engineering Materials 18, 490-495. DOI: 10.1002/adem.201500509.

Table S-3. Extract of materials inventory for the manufacturing of $1 \mathrm{~m}^{2}$ OPV solar modules (50\%active area) with four different electrodes

\begin{tabular}{lllll}
\hline Layer & Silver & Carbon & Aluminium & Copper \\
\hline
\end{tabular}

\section{Front electrode}

Inputs

$\begin{array}{rcccc}\text { Substrate PET } & 0.178 & 0.178 & 0,178 & 0,178 \\ \text { Front electrode ink } & 5.9 \mathrm{E}-04 & - & 7,8 \mathrm{E}-03 & 5,5 \mathrm{E}-03 \\ \text { Electricity }(\mathrm{kWh}) & 6.4 \mathrm{E}-02 & - & 6,4 \mathrm{E}-02 & 6,4 \mathrm{E}-02 \\ \text { Transport (ton } / \mathrm{km}) & 3.9 \mathrm{E}-03 & - & 5,2 \mathrm{E}-02 & 3,6 \mathrm{E}-02\end{array}$

Outputs

$$
\text { Water to air }
$$

$0,0 \mathrm{E}+00$

2,7E-03

Propylene glycol methyl ether acetate

$$
\text { to air }
$$

Metal to water

$1.4 \mathrm{E}-08$

4,7E-03

$1.2 \mathrm{E}-07$

1.1E-07

Hole injection layer ${ }^{a}$

Active layer( blend (1:1)) ${ }^{\mathrm{a}}$

\section{Back electrode}

Inputs

$\begin{array}{rrrrr}\text { Back electrode ink }^{\mathrm{b}} & 6.56 \mathrm{E}-03 & 5.22 \mathrm{E}-03 & 6,56 \mathrm{E}-03 & 6,56 \mathrm{E}-03 \\ \text { Electricity }(\mathrm{kWh}) & 1.43 \mathrm{E}-01 & 3.57 \mathrm{E}-01 & 1.43 \mathrm{E}-01 & 1.43 \mathrm{E}-01 \\ \text { Transport (ton } / \mathrm{km}) & 8.20 \mathrm{E}-03 & 3.50 \mathrm{E}-02 & 8.20 \mathrm{E}-03 & 8.20 \mathrm{E}-03\end{array}$

Outputs

Propylene glycol methyl ether acetate to air 2-[2-(2-Ethoxyethoxy)ethoxy]ethanol

$\begin{array}{lccc}4.30 \mathrm{E}-03 & 4.30 \mathrm{E}-03 & 4,30 \mathrm{E}-03 & 4,30 \mathrm{E}-03 \\ 3.28 \mathrm{E}-06 & - & 3,28 \mathrm{E}-06 & 3,28 \mathrm{E}-06 \\ 5.91 \mathrm{E}-08 & - & 5,91 \mathrm{E}-08 & 5,91 \mathrm{E}-08 \\ 1.88 \mathrm{E}-07 & 1.19 \mathrm{E}-05 & 1,88 \mathrm{E}-07 & 1,88 \mathrm{E}-07\end{array}$

\section{Encapsulation $^{\mathrm{a}}$}

Propanol, (2-(2methoxymethylethoxy)methylethoxy)-

\section{Solvents or cleaners ${ }^{\mathrm{a}}$}

\footnotetext{
${ }^{\mathrm{a}}$ Detailed inventory for $1 \mathrm{~m}^{2}$ of OPV modules can be found in Espinosa et al. ${ }^{[2]}$

${ }^{\mathrm{b}}$ Back electrode is always silver except for the carbon electrode modules
} 


\section{Disposal assumptions}

The disposal stage has been done in accordance with the scenarios considered in a previous work.

The main features for the modelling are shown in Table S4.

Table S-4. Modelling of disposal scenarios. More details in Espinosa et al. ${ }^{[2]} \mathrm{RE}$ refers to Recycling, IN to incineration and L to landfill.

\begin{tabular}{|c|c|c|}
\hline Scenario & Description & Modelling and Assumptions \\
\hline DK-1 & $\begin{array}{l}\text { Recycling. Solar cells are assumed to } \\
\text { be collected by a specialized } \\
\text { company, which will extract valuable } \\
\text { materials (PET + silver). This could } \\
\text { also be assumed to be the likely } \\
\text { scenario in case of handling of solar } \\
\text { cells as industrial or hazardous waste. }\end{array}$ & $\begin{array}{l}\text { Recycling pathways with PET recovered from } \\
\text { delamination (sent to recycling) and silver } \\
\text { recovered from acid treatment. Incineration of } \\
\text { the mixed plastics and remains with energy } \\
\text { recovery }\end{array}$ \\
\hline DK-2 & $\begin{array}{l}\text { Incineration. Due to the high caloric } \\
\text { value from plastic content, solar cells } \\
\text { are assumed to be collected and } \\
\text { directly sent to municipal } \\
\text { incineration. This represents } \\
\text { controlled deployment) }\end{array}$ & $\begin{array}{l}\text { Incineration modelled as PET municipal } \\
\text { incineration (energy recovery); no } \\
\text { differentiation due to composition of solar } \\
\text { cells. }\end{array}$ \\
\hline DK-3 & $\begin{array}{l}\text { Average mix of MSW: } 29 \% \text { RE, } 69 \% \\
\text { IN, } 2 \% \text { L. It is assumed to represent a } \\
\text { large and diffuse deployment of solar } \\
\text { cells in Denmark. }\end{array}$ & $\begin{array}{l}\text { Recycling path follows Scenario DK-1. } \\
\text { Incineration path follows Scenario DK- } 2 \text {. } \\
\text { Landfill is modelled as landfill of PET with } \\
\text { amount of Ag corrected to match content of } \\
\text { Ag of the solar cells: distinction between } \\
\text { short-term and long-term emissions is } \\
\text { performed: } 1 \% \text { vs. } 99 \% \text { done. }\end{array}$ \\
\hline
\end{tabular}


Table S-5. Scenarios of disposal.

\begin{tabular}{rll}
\hline Scenarios & Rationale & $\begin{array}{l}\text { Type of } \\
\text { electrode }\end{array}$ \\
\hline 1 & All in DK and disposal DK-1 & Silver \\
2 & All in DK and disposal DK-2 & Silver \\
3 & All in DK and disposal DK-3 & Silver \\
4 & All in DK and disposal DK-1 & Aluminium \\
5 & All in DK and disposal DK-2 & Aluminium \\
6 & All in DK and disposal DK-3 & Aluminium \\
7 & All in DK and disposal DK-1 & Copper \\
8 & All in DK and disposal DK-2 & Copper \\
9 & All in DK and disposal DK-3 & Copper \\
10 & All in DK and disposal DK-1 & Carbon \\
11 & All in DK and disposal DK-2 & Carbon \\
12 & All in DK and disposal DK-3 & Carbon \\
\hline
\end{tabular}

Table S-6. Recovery rate of materials considered in the recycling. For the acid recovery the data comes from ${ }^{[14]}$ and for the metals from ${ }^{[26]}$

\begin{tabular}{lr}
\hline Materials & Recycling rate \\
\hline Acid & $95 \%$ \\
Copper & $76 \%$ \\
Silver in recycling of solar cells & $95 \%$ \\
Silver in incineration of solar cells & $95 \%$ \\
Aluminium from solar cells & $95 \%$ \\
Copper in recycling of solar cells & $95 \%$ \\
PET & $88 \%$
\end{tabular}


Table S-7. Results of the impact assessment for $1 \mathrm{kWh}$ produced from modules using Silver, in the three scenarios considered DK-1, recycling scenario, DK-2 incineration and DK-3 Danish scenario.

\begin{tabular}{|c|c|c|c|c|c|}
\hline & Production & $\begin{array}{l}\text { Disposal } \\
\text { DK-1 }\end{array}$ & $\begin{array}{l}\text { Total } \\
\text { DK-1 }\end{array}$ & $\begin{array}{l}\text { Total } \\
\text { DK-2 }\end{array}$ & $\begin{array}{l}\text { Total } \\
\text { DK-3 }\end{array}$ \\
\hline $\begin{array}{l}\text { Climate change } \\
\text { (kg-CO } \mathrm{C}_{2} \mathrm{eq} / \text { pers) }\end{array}$ & 7,88E-01 & 4,54E-01 & 7,95E-01 & 6,96E-01 & $7,88 \mathrm{E}-01$ \\
\hline $\begin{array}{l}\text { Ozone depletion } \\
\text { (kg CFC-11 eq) }\end{array}$ & 5,57E-08 & 6,60E-09 & 5,33E-08 & 3,98E-08 & 5,57E-08 \\
\hline $\begin{array}{l}\text { Photochemical ozone } \\
\text { formation (kg NMVOC eq) }\end{array}$ & 6,84E-03 & 2,36E-03 & 6,76E-03 & 5,49E-03 & 6,84E-03 \\
\hline Acidification (mol H+ eq) & 9,13E-03 & 3,31E-03 & 8,98E-03 & 7,33E-03 & 9,13E-03 \\
\hline $\begin{array}{l}\text { Terrestrial eutrophication } \\
\text { (mol N eq) }\end{array}$ & 2,95E-02 & $1,05 \mathrm{E}-02$ & 2,93E-02 & 2,39E-02 & 2,95E-02 \\
\hline $\begin{array}{l}\text { Freshwater eutrophication } \\
\text { (kg-Peq/pers) }\end{array}$ & 4,08E-03 & $1,18 \mathrm{E}-03$ & 4,07E-03 & 3,23E-03 & 4,08E-03 \\
\hline $\begin{array}{l}\text { Marine eutrophication } \\
\text { (kg-Neq/pers) }\end{array}$ & 2,50E-03 & $8,22 \mathrm{E}-04$ & $2,48 \mathrm{E}-03$ & 2,00E-03 & 2,50E-03 \\
\hline $\begin{array}{l}\text { Freshwater ecotoxicity } \\
\text { (CTUe/pers) }\end{array}$ & $1,56 \mathrm{E}+02$ & $4,64 \mathrm{E}+01$ & $1,56 \mathrm{E}+02$ & $1,26 \mathrm{E}+02$ & $1,56 \mathrm{E}+02$ \\
\hline $\begin{array}{l}\text { Human toxicity, cancer effects } \\
\text { (CTUh/pers) }\end{array}$ & 2,48E-07 & 7,53E-08 & 2,47E-07 & 1,97E-07 & 2,48E-07 \\
\hline $\begin{array}{l}\text { Human toxicity, non-cancer } \\
\text { effects (CTUh/pers) }\end{array}$ & 6,39E-06 & 1,80E-06 & 6,37E-06 & 5,05E-06 & 6,39E-06 \\
\hline $\begin{array}{l}\text { Respiratory inorganics } \\
\text { (kg-PM } \mathbf{M}_{2.5} \text { eq/pers) }\end{array}$ & 8,28E-04 & 2,72E-04 & 7,80E-04 & 6,34E-04 & 8,28E-04 \\
\hline $\begin{array}{l}\text { Ionizing radiation } \\
\text { (kBq- } \mathbf{U}_{235} \mathbf{e q} / \text { pers) }\end{array}$ & 1,12E-01 & 2,47E-02 & $1,12 \mathrm{E}-01$ & 8,68E-02 & 1,12E-01 \\
\hline Land use (kg C deficit) & $8,72 E+00$ & $2,57 \mathrm{E}+00$ & $8,65 \mathrm{E}+00$ & $6,89 \mathrm{E}+00$ & $8,72 E+00$ \\
\hline $\begin{array}{l}\text { Water resource depletion }\left(\mathrm{m}^{3}\right. \\
\text { water) }\end{array}$ & 2,58E-03 & 1,17E-03 & 2,57E-03 & 2,16E-03 & 2,58E-03 \\
\hline $\begin{array}{l}\text { Resource depletion } \\
\text { (kg-Sbeq/pers) }\end{array}$ & 4,16E-03 & 1,16E-03 & 4,16E-03 & 3,29E-03 & 4,16E-03 \\
\hline
\end{tabular}


Table S-8. Results of the impact assessment for $1 \mathrm{kWh}$ produced from Aluminium-electrode modules, in the three scenarios considered DK-1, recycling scenario, DK-2 incineration and DK-3 Danish scenario.

\begin{tabular}{|c|c|c|c|c|c|}
\hline & Production & $\begin{array}{l}\text { Disposal } \\
\text { DK-1 }\end{array}$ & $\begin{array}{l}\text { Total } \\
\text { DK-1 }\end{array}$ & $\begin{array}{l}\text { Total } \\
\text { DK-2 }\end{array}$ & $\begin{array}{l}\text { Total } \\
\text { DK-3 }\end{array}$ \\
\hline $\begin{array}{l}\text { Climate change } \\
\left.\text { (kg-COت } \mathrm{CO}_{2} \mathrm{eq} / \mathrm{pers}\right)\end{array}$ & 7,50E-01 & $4,57 \mathrm{E}-01$ & $7,57 \mathrm{E}-01$ & $6,70 \mathrm{E}-01$ & $7,50 \mathrm{E}-01$ \\
\hline $\begin{array}{l}\text { Ozone depletion } \\
\text { (kg CFC-11 eq) }\end{array}$ & 5,78E-08 & 1,19E-08 & 5,54E-08 & $4,28 \mathrm{E}-08$ & 5,78E-08 \\
\hline $\begin{array}{l}\text { Photochemical ozone } \\
\text { formation (kg NMVOC eq) }\end{array}$ & $6,41 \mathrm{E}-03$ & 2,24E-03 & 6,33E-03 & $5,14 \mathrm{E}-03$ & $6,41 \mathrm{E}-03$ \\
\hline Acidification (mol H+ eq) & 8,57E-03 & 3,12E-03 & 8,41E-03 & 6,88E-03 & 8,57E-03 \\
\hline $\begin{array}{l}\text { Terrestrial eutrophication } \\
\text { (mol } \mathbf{N} \text { eq) }\end{array}$ & 2,76E-02 & 1,00E-02 & 2,73E-02 & 2,23E-02 & 2,76E-02 \\
\hline $\begin{array}{l}\text { Freshwater eutrophication } \\
\text { (kg-Peq/pers) }\end{array}$ & 3,79E-03 & 1,09E-03 & 3,78E-03 & 3,00E-03 & 3,79E-03 \\
\hline $\begin{array}{l}\text { Marine eutrophication } \\
\text { (kg-Neq/pers) }\end{array}$ & 2,33E-03 & 7,69E-04 & 2,31E-03 & 1,87E-03 & 2,33E-03 \\
\hline $\begin{array}{l}\text { Freshwater ecotoxicity } \\
\text { (CTUe/pers) }\end{array}$ & $1,45 E+02$ & $4,35 E+01$ & $1,45 E+02$ & $1,17 \mathrm{E}+02$ & $1,45 E+02$ \\
\hline $\begin{array}{l}\text { Human toxicity, cancer effects } \\
\text { (CTUh/pers) }\end{array}$ & 2,32E-07 & 7,02E-08 & 2,31E-07 & 1,84E-07 & 2,32E-07 \\
\hline $\begin{array}{l}\text { Human toxicity, non-cancer } \\
\text { effects (CTUh/pers) }\end{array}$ & 5,94E-06 & 1,67E-06 & 5,92E-06 & 4,69E-06 & 5,94E-06 \\
\hline $\begin{array}{l}\text { Respiratory inorganics } \\
\text { (kg-PM } 2.5 \text { eq/pers) }\end{array}$ & 7,78E-04 & 2,54E-04 & 7,30E-04 & 5,93E-04 & 7,78E-04 \\
\hline $\begin{array}{l}\text { Ionizing radiation } \\
\text { (kBq-U } \mathbf{U}_{235} \mathbf{e q} / \text { pers) }\end{array}$ & 1,05E-01 & 8,02E-03 & 1,04E-01 & 7,64E-02 & 1,05E-01 \\
\hline Land use (kg C deficit) & $8,10 \mathrm{E}+00$ & $2,42 E+00$ & $8,03 E+00$ & $6,41 E+00$ & $8,10 \mathrm{E}+00$ \\
\hline $\begin{array}{l}\text { Water resource depletion }\left(\mathrm{m}^{3}\right. \\
\text { water) }\end{array}$ & $2,46 \mathrm{E}-03$ & 1,20E-03 & $2,46 E-03$ & 2,09E-03 & 2,46E-03 \\
\hline $\begin{array}{l}\text { Resource depletion } \\
\text { (kg-Sbeq/pers) }\end{array}$ & 3,86E-03 & 1,08E-03 & 3,86E-03 & 3,06E-03 & 3,86E-03 \\
\hline
\end{tabular}


Table S-9. Results of the impact assessment for $1 \mathrm{kWh}$ produced from Copper -electrode modules, in the three scenarios considered DK-1, recycling scenario, DK-2 incineration and DK-3 Danish scenario.

\begin{tabular}{|c|c|c|c|c|c|}
\hline & Production & $\begin{array}{l}\text { Disposal } \\
\text { DK-1 }\end{array}$ & $\begin{array}{l}\text { Total } \\
\text { DK-1 }\end{array}$ & $\begin{array}{l}\text { Total } \\
\text { DK-2 }\end{array}$ & $\begin{array}{l}\text { Total } \\
\text { DK-3 }\end{array}$ \\
\hline $\begin{array}{l}\text { Climate change } \\
\text { (kg-CO } \mathrm{O}_{2} \mathrm{eq} / \text { pers) }\end{array}$ & 7,54E-01 & $4,55 \mathrm{E}-01$ & $7,61 \mathrm{E}-01$ & 6,72E-01 & $7,54 \mathrm{E}-01$ \\
\hline $\begin{array}{l}\text { Ozone depletion } \\
\text { (kg CFC-11 eq) }\end{array}$ & 5,26E-08 & 6,07E-09 & 5,02E-08 & 3,74E-08 & $5,26 \mathrm{E}-08$ \\
\hline $\begin{array}{l}\text { Photochemical ozone } \\
\text { formation (kg NMVOC } \\
\text { eq) }\end{array}$ & $6,42 \mathrm{E}-03$ & 2,25E-03 & 6,34E-03 & 5,16E-03 & $6,42 \mathrm{E}-03$ \\
\hline $\begin{array}{l}\text { Acidification (mol H+ } \\
\text { eq) }\end{array}$ & 8,64E-03 & 3,20E-03 & 8,49E-03 & 6,96E-03 & 8,64E-03 \\
\hline $\begin{array}{l}\text { Terrestrial } \\
\text { eutrophication (mol N } \\
\text { eq) }\end{array}$ & 2,76E-02 & 1,00E-02 & 2,74E-02 & 2,24E-02 & 2,76E-02 \\
\hline $\begin{array}{l}\text { Freshwater } \\
\text { eutrophication (kg- } \\
\text { Peq/pers) }\end{array}$ & 3,82E-03 & $1,11 \mathrm{E}-03$ & 3,81E-03 & 3,03E-03 & 3,82E-03 \\
\hline $\begin{array}{l}\text { Marine eutrophication } \\
\text { (kg-Neq/pers) }\end{array}$ & 2,34E-03 & 7,81E-04 & 2,32E-03 & 1,88E-03 & 2,34E-03 \\
\hline $\begin{array}{l}\text { Freshwater ecotoxicity } \\
\text { (CTUe/pers) }\end{array}$ & $1,46 \mathrm{E}+02$ & $4,40 \mathrm{E}+01$ & $1,46 \mathrm{E}+02$ & $1,18 \mathrm{E}+02$ & $1,46 \mathrm{E}+02$ \\
\hline $\begin{array}{l}\text { Human toxicity, cancer } \\
\text { effects (CTUh/pers) }\end{array}$ & 2,33E-07 & $7,14 \mathrm{E}-08$ & 2,31E-07 & $1,85 \mathrm{E}-07$ & 2,33E-07 \\
\hline $\begin{array}{l}\text { Human toxicity, non- } \\
\text { cancer effects } \\
\text { (CTUh/pers) }\end{array}$ & 5,98E-06 & 1,69E-06 & 5,96E-06 & 4,73E-06 & 5,98E-06 \\
\hline $\begin{array}{l}\text { Respiratory inorganics } \\
\text { (kg-PM }_{2.5} \text { eq/pers) }\end{array}$ & 7,82E-04 & 2,61E-04 & 7,34E-04 & $5,98 \mathrm{E}-04$ & 7,82E-04 \\
\hline $\begin{array}{l}\text { Ionizing radiation } \\
\text { (kBq- } \mathrm{U}_{235} \mathbf{e q} / \text { pers) }\end{array}$ & 1,05E-01 & 1,91E-02 & $1,05 \mathrm{E}-01$ & 7,98E-02 & $1,05 \mathrm{E}-01$ \\
\hline Land use (kg C deficit) & $8,12 E+00$ & $2,42 \mathrm{E}+00$ & $8,05 E+00$ & $6,42 \mathrm{E}+00$ & $8,12 E+00$ \\
\hline $\begin{array}{l}\text { Water resource } \\
\text { depletion }\left(\mathbf{m}^{3} \text { water }\right)\end{array}$ & 2,47E-03 & $1,14 \mathrm{E}-03$ & 2,47E-03 & 2,08E-03 & 2,47E-03 \\
\hline $\begin{array}{l}\text { Resource depletion } \\
\text { (kg-Sbeg/pers) }\end{array}$ & 3,87E-03 & 1,08E-03 & 3,87E-03 & 3,06E-03 & 3,87E-03 \\
\hline
\end{tabular}


Table S-10. Results of the impact assessment for $1 \mathrm{kWh}$ produced from Carbon -electrode modules, in the three scenarios considered DK-1, recycling scenario, DK-2 incineration and DK-3 Danish scenario.

\begin{tabular}{|c|c|c|c|c|c|}
\hline & Production & $\begin{array}{l}\text { Disposal } \\
\text { DK-1 } \\
\end{array}$ & $\begin{array}{l}\text { Total } \\
\text { DK-1 } \\
\end{array}$ & $\begin{array}{l}\text { Total } \\
\text { DK-2 }\end{array}$ & $\begin{array}{l}\text { Total } \\
\text { DK-3 } \\
\end{array}$ \\
\hline $\begin{array}{l}\text { Climate change } \\
\text { (kg-CO } \mathrm{C}_{2} \mathrm{eq} / \text { pers) }\end{array}$ & 2,32E-01 & 3,04E-01 & $2,41 \mathrm{E}-01$ & 2,59E-01 & 2,32E-01 \\
\hline $\begin{array}{l}\text { Ozone depletion } \\
\text { (kg CFC-11 eq) }\end{array}$ & $1,48 \mathrm{E}-08$ & $1,20 \mathrm{E}-08$ & 1,15E-08 & 1,17E-08 & $1,48 \mathrm{E}-08$ \\
\hline $\begin{array}{l}\text { Photochemical ozone } \\
\text { formation (kg NMVOC eq) }\end{array}$ & 7,30E-04 & $6,75 \mathrm{E}-04$ & $6,21 \mathrm{E}-04$ & 6,39E-04 & $7,30 \mathrm{E}-04$ \\
\hline Acidification (mol H+ eq) & 1,05E-03 & $1,05 \mathrm{E}-03$ & $8,41 \mathrm{E}-04$ & $9,06 \mathrm{E}-04$ & 1,05E-03 \\
\hline $\begin{array}{l}\text { Terrestrial eutrophication } \\
\text { (mol N eq) }\end{array}$ & 1,76E-03 & $1,66 \mathrm{E}-03$ & $1,42 \mathrm{E}-03$ & $1,50 \mathrm{E}-03$ & $1,76 \mathrm{E}-03$ \\
\hline $\begin{array}{l}\text { Freshwater eutrophication } \\
\text { (kg-Peq/pers) }\end{array}$ & 7,98E-05 & $1,02 \mathrm{E}-04$ & 6,90E-05 & 7,89E-05 & 7,98E-05 \\
\hline $\begin{array}{l}\text { Marine eutrophication } \\
\text { (kg-Neq/pers) }\end{array}$ & 1,71E-04 & $1,71 \mathrm{E}-04$ & $1,44 \mathrm{E}-04$ & $1,54 \mathrm{E}-04$ & $1,71 \mathrm{E}-04$ \\
\hline $\begin{array}{l}\text { Freshwater ecotoxicity } \\
\text { (CTUe/pers) }\end{array}$ & $3,30 \mathrm{E}+00$ & $5,37 \mathrm{E}+00$ & $4,01 \mathrm{E}+00$ & $4,43 E+00$ & $3,30 \mathrm{E}+00$ \\
\hline $\begin{array}{l}\text { Human toxicity, cancer } \\
\text { effects (CTUh/pers) }\end{array}$ & 1,17E-08 & $1,34 \mathrm{E}-08$ & $1,02 \mathrm{E}-08$ & 1,11E-08 & 1,17E-08 \\
\hline $\begin{array}{l}\text { Human toxicity, non-cancer } \\
\text { effects (CTUh/pers) }\end{array}$ & 5,88E-08 & 5,57E-08 & 3,98E-08 & 4,50E-08 & 5,88E-08 \\
\hline $\begin{array}{l}\text { Respiratory inorganics } \\
\text { (kg-PM }{ }_{2.5} \text { eq/pers) }\end{array}$ & $1,18 \mathrm{E}-04$ & 7,22E-05 & 5,27E-05 & 5,98E-05 & 1,18E-04 \\
\hline $\begin{array}{l}\text { Ionizing radiation } \\
\text { (kBq- } \mathbf{U}_{235} \mathbf{e q} / \text { pers) }\end{array}$ & 4,50E-03 & 4,24E-03 & 4,27E-03 & 4,27E-03 & 4,50E-03 \\
\hline Land use (kg C deficit) & 2,38E-01 & $1,94 \mathrm{E}-01$ & 1,43E-01 & $1,60 \mathrm{E}-01$ & 2,38E-01 \\
\hline $\begin{array}{l}\text { Water resource depletion } \\
\left(\mathrm{m}^{3} \text { water }\right)\end{array}$ & 1,16E-03 & 1,03E-03 & 1,16E-03 & $1,12 \mathrm{E}-03$ & 1,16E-03 \\
\hline $\begin{array}{l}\text { Resource depletion } \\
\text { (kg-Sbeq/pers) }\end{array}$ & 7,35E-06 & 5,74E-06 & 7,04E-06 & 6,67E-06 & 7,35E-06 \\
\hline
\end{tabular}


Table S-11. Results of the impact assessment for $1 \mathrm{kWh}$ produced from a single-Si wafer photovoltaic panel - for which 5,41E-4 $\mathrm{m}^{2}$ are required. The variation with respect to the production of a carbon-based OPV module is also shown in the column at the right.

\begin{tabular}{lcc} 
& $\begin{array}{c}\text { Si PV panel } \\
\text { production }\end{array}$ & $\begin{array}{c}\text { \% Increase over C- } \\
\text { OPV module prod. }\end{array}$ \\
\hline Climate change (kg-CO $\mathbf{2}$ eq/pers) & $1,79 \mathrm{E}-01$ & $77 \%$ \\
Ozone depletion (kg CFC-11 eq) & $2,51 \mathrm{E}-08$ & $169 \%$ \\
Photochemical ozone formation (kg NMVOC eq) & $7,52 \mathrm{E}-04$ & $169 \%$ \\
Acidification (mol H+ eq) & $1,50 \mathrm{E}-03$ & $255 \%$ \\
Terrestrial eutrophication (mol N eq) & $2,23 \mathrm{E}-03$ & $170 \%$ \\
Freshwater eutrophication (kg-Peq/pers) & $1,37 \mathrm{E}-04$ & $472 \%$ \\
Marine eutrophication (kg-Neq/pers) & $2,27 \mathrm{E}-04$ & $103 \%$ \\
Freshwater ecotoxicity (CTUe/pers) & $3,74 \mathrm{E}+00$ & $143 \%$ \\
Human toxicity, cancer effects (CTUh/pers) & $1,97 \mathrm{E}-08$ & $127 \%$ \\
Human toxicity, non-cancer effects (CTUh/pers) & $1,50 \mathrm{E}-07$ & $172 \%$ \\
Respiratory inorganics (kg-PM2.5eq/pers) & $2,00 \mathrm{E}-04$ & $132 \%$ \\
Ionizing radiation (kBq-U235eq/pers) & $2,12 \mathrm{E}-02$ & $113 \%$ \\
Land use (kg C deficit) & $2,84 \mathrm{E}-01$ & $119 \%$ \\
Water resource depletion (m ${ }^{3}$ water) & $2,12 \mathrm{E}-03$ & $182 \%$ \\
Resource depletion (kg-Sbeq/pers) & $6,294 \mathrm{E}-05$ & $856 \%$ \\
\hline
\end{tabular}

